\title{
Influence of dinoflagellate cell toxicity on uptake and loss of paralytic shellfish toxins in the northern quahog Mercenaria mercenaria*
}

\author{
V. M. Bricelj ${ }^{1}$, J. H. Lee ${ }^{1}$, A. D. Cembella ${ }^{2, *}$ \\ ${ }^{1}$ Marine Sciences Research Center, State University of New York, Stony Brook, New York 11794, USA \\ ${ }^{2}$ Maurice Lamontagne Institute, Department of Fisheries and Oceans, 850 route de la mer, PO Box 1000, Mont Joli, Quebec, \\ Canada G5H $3 Z 4$
}

\begin{abstract}
The northern quahog Mercenaria mercenaria was exposed to bloom concentrations of the toxic red-tide dinoflagellate Alexandrium, the proximal cause of paralytic shellfish poisoning (PSP) in eastern North America, under controlled conditions in the laboratory. Two cultured isolates of Alexandrium, exhibiting markedly different PSP toxin compositions and specific toxicities, were used independently to determine the kinetics of toxin accumulation and loss, as well as the potential for biotransformation of individual PSP toxins in certain tissues. Clams readily ingested and absorbed a monospecific diet of the low toxicity A. tamarense isolate GtLI22. They also ingested cells of the high toxicity A. fundyense isolate GtCA29, but at a lower rate, and only when the diet was supplemented with a nontoxic diatom. Thalassiosira weissflogii. As natural populations of $M$. mercenaria rarely accumulate a substantial PSP toxin load, this suggests the existence of a toxin recognition mechanism. Maximum toxicities in clam tissues, attained within $2 \mathrm{wk}$ of exposure to either toxic dinoflagellate, exceeded the regulatory harvest closure level $\left(80 \mu \mathrm{g}\right.$ STXeq $\left.100 \mathrm{~g}^{-1}\right)$ by several orders of magnitude. Detoxification to levels acceptable for human consumption occurred within 3 to $6 \mathrm{wk}$. HPLC analyses revealed significant differences between the toxic profile of the dinoflagellates and that accumulated in various clam tissues. Clams toxified with isolate GtLI22, a strain rich in low potency C-toxins, showed: (1) de novo appearance of STX, (2) significant reduction in the proportion of C-toxins, and (3) reciprocal increase in the proportion of the gonyautoxins GTX $_{2+3}$. Significant relative enrichment in STX also occurred in tissues of clams fed upon GtCA.29, an isolate rich in the more potent carbamate toxins. The first experimental evidence of PSP accumulation/detoxification by $M$. mercenaria is provided, underscoring the potential of this species to act as a vector of PSP in humans.
\end{abstract}

\section{INTRODUCTION}

Certain species of the dinoflagellate genus Alexandrium (Halim) Balech [conspecific or synonymous with members of Protogonyaulax (Lebour) Taylor] produce potent neurotoxins - saxitoxin (STX) and its derivatives. These toxins accumulate in suspension-feeding bivalves through grazing on natural phytoplankton populations, causing outbreaks worldwide of paralytic

- Contribution no. 804 from the Marine Sciences Research Center, SUNY Stony Brook

- Present address: Institute for Marine Biosciences, National Research Council, 1441 Oxford Street, Halifax, N. S., Canada B3H $3 Z 1$ shellfish poisoning (PSP). In the various strains of Alexandrium spp. responsible for PSP in eastern Canada and northeastern USA, at least 10 STX-derivatives, varying widely in potency, have been identified (Cembella et al. 1987, Anderson 1990) (Fig. 1).

Cell toxicity in cultured isolates of Alexandrium from the eastern coast of North America, as determined by mouse bioassay, was found to range from undetectable levels to $>100 \mathrm{pg}$ saxitoxin equivalents (STXeq) cell ${ }^{-1}$, with toxicity generally decreasing (albeit irregularly) along a north to south latitudinal gradient from the estuary and Gulf of St. Lawrence through the Bay of Fundy, Canada, and the Gulf of Maine, to Long Island, New York, USA (Maranda et al. 1985, Cembella et al. 1988). Alexandrium isolates are known to differ in their 
characteristic toxin profiles or 'signatures' (Cembella et al. 1987). The general tendency towards greater toxicity in northern strains is not only due to higher PSP toxin quota per cell, but also partially reflects a predominance of more potent carbamate toxins as compared to southern strains which typically contain higher proportions of the less toxic $\mathrm{N}$-sulfocarbamoyl toxins (Anderson 1990). These so-called cryptic toxins are highly labile and thus can potentially be converted to their more toxic carbamate analogues in bivalve tissues (Hall \& Reichardt 1984).

Widespread occurrence of resting cysts (hypnozygotes) of Alexandrium in sediments (Anderson et al. 1982), and toxic vegetative cells at densities of up to $2 \times 10^{5}$ cells $1^{-1}$ (Schrey et al. 1984), have been documented in Long Island estuaries. Maranda et al. (1985) hypothesized that the historical absence of PSP in this region may be attributed to the low toxicity of southern isolates of Alexandrium $\left(<7 \mathrm{pg}\right.$ STXeq cell $\left.{ }^{-1}\right)$. Alternatively, unfavorable hydrodynamic conditions, interspecific competition for limiting resources, or intense grazing pressure may so far have prevented the development of persistent blooms in the Long Island region. The potential threat of PSP to commercially exploited bivalve populations in this and other coastal areas where low toxicity dinoflagellate strains are prevalent remains to be assessed.

Differences in toxin levels among bivalve populations may be influenced by their history of toxin exposure: bloom duration, dinoflagellate abundance and toxicity per cell. Interspecific differences in the maximum PSP toxin levels attained, and in the rates of toxin incorporation and loss, are also well documented (Dupuy 1968 . Hurst \& Gilfillan 1977, Shumway et al. 1988, Lassus et al. 1989, Bricelj et al. 1990). Further, bivalve molluscs are known to differ greatly in their sensitivity to STX, as measured in vitro by its blocking effect on conduction of the nerve impulse. The blue mussel Mytilus edulis (Twarog et al. 1972) and butter clam Saxidomus giganteus (Kvitek \& Beitler 1991) are highly resistant to STX and are also capable of sequestering high toxin loads during toxic blooms. In contrast, oysters Crassostrea virginica are highly sensitive to STX, and attain only low or undetectable toxin levels during toxic blooms (Shumway 1990a). Such sensitive species often exhibit protective behavioral or physiological responses when feeding upon PSP-toxin-producing dinoflagellates, e.g. shellvalve closure, siphon retraction or reduced filtration rates (Shumway \& Cucci 1987).

The northern quahog or hard clam Mercenaria mercenaria (Linnaeus 1758), an important commercially exploited bivalve species on the east coast of the USA, shows anomalous behavior in response to PSP toxins, and does not readily fit into the ranking proposed by Twarog et al. (1972), in which the bivalve species most resistant to STX also tend to be those capable of achieving the highest toxicities. M. mercenaria is relatively resistant to STX, and yet is generally reported to remain non-toxic during red tides of Alexandrium. For example, during the 1972 New England red tide, hard clams and oysters remained non-toxic while co-occurring bay scallops Argopecten irradians and mussels Mytilus edulis attained toxin levels of 2000 to $2600 \mu \mathrm{g}$ STXeq $100 \mathrm{~g}^{-1}$ (Twarog \& Yamaguchi 1974, Shumway $1990 \mathrm{~b}$ ). (In the USA, closures of shellfish grounds are required when toxicities exceed a regulatory level of $80 \mu \mathrm{g}$ STXeq $100 \mathrm{~g}^{-1}$ wet weight of total shellfish tissue.) Previous laboratory attempts to induce toxicity in hard clams by exposing them for $2 \mathrm{~d}$ to typical bloom densities $\left(4 \times 10^{5}\right.$ cells $\left.^{-1}\right)$ of monospecific cultures of Alexandrium tamarense (Clone Gt429) were unsuccessful and resulted in shell-valve closure (Shumway $1990 \mathrm{~b}$, pers. comm.). Toxic $M$. mercenaria have been reported in the Bay of Fundy and St. Lawrence estuary of eastern Canada (Bond \& Lachance 1959), and toxin levels in hard clams from Maine coastal waters have reached $1100 \mu \mathrm{g}$ STXeq $100 \mathrm{~g}^{-1}$, a level only 4 times less than that of $M$. edulis from the same site (Shumway pers. comm.).

The main purpose of this study was to determine experimentally whether or not Mercenaria mercenaria is capable of accumulating PSP toxins and thereby act as a vector of PSP. The conditions (especially those related to cell toxicity) under which this may occur were investigated under a controlled feeding regime. The specific objectives were to describe quantitatively: (1) the kinetics of PSP toxin incorporation and loss in this species, and (2) the localization and fate of individual toxins in different clam tissues following exposure to 2 Alexandrium isolates differing markedly in specific toxicity per cell and toxin composition.

\section{METHODS}

Two toxic dinoflagellate isolates were obtained from D. M. Anderson (Woods Hole Oceanographic Institute culture collection, Woods Hole, MA, USA): Alexandrium fundyense, Clone GtCA29, from the Gulf of Maine, New Hampshire, USA $\left(43^{\circ} \mathrm{N}\right)$, and $A$. tamarense, Clone GtLI22, from Long Island waters (Mud Creek, Babylon, New York, 40 40 N). Based upon isozyme electrophoretic data, these 2 species are closely related and are separated only on the basis of minor morphological characteristics (Hayhome et al. 1989). Mean toxicities determined by high-performance liquid chromatography (HPLC) analysis of cells in exponential growth phase were 96.5 and $5.9 \mathrm{pg}$ STXeq cell $^{-1}$ for GtCA29 and GtLI22, respectively. The 2 clones were identical in mean cell diameter $(28 \mu \mathrm{m})$, 
but differed in toxin composition (Table 1): isolate GtCA29 was rich in the carbamate toxins STX and GTX $_{2+3}$, which together comprised an average of $74 \%$ of total cell toxicity, whereas $\mathrm{N}$-sulfocarbamoyl toxins were predominant in GtLI22 $\left(\mathrm{C}_{1,2}=66 \%\right.$ of total toxicity).

Unialgal isolates were mass cultured and used independently to expose juvenile hard clams Mercenaria mercenaria to PSP toxins. The Alexandrium isolates were grown in non-axenic batch culture in $\mathrm{K}$ medium (Keller et al. 1987) on a $16: 8 \mathrm{~h} \mathrm{light/dark}$ cycle at $17^{\circ} \mathrm{C}$. The non-toxic diatom Thalassiosira weissflogii $(11 \mu \mathrm{m}$ equivalent spherical diameter), used as a feeding supplement, was grown in $\mathrm{f} / 2$ medium (Guillard \& Ryther 1962 ) at $20^{\circ} \mathrm{C}$. All algae were harvested from aerated 201 carboys in late logarithmic growth phase. Prior to preparation of feeding suspensions, dinoflagellate cells were concentrated by sieving onto a $20 \mu \mathrm{m}$ Nitex mesh, and their concentration was determined microscopically with a Sedgwick-Rafter counting chamber. Cell densities of $T$. weissflogii cultures were determined microscopically with a hemacytometer following concentration by centrifugation, while those in the experimental tank were determined using a Coulter Counter equipped with a $120 \mu \mathrm{m}$ orifice.

Clams with no prior history of exposure to PSP were obtained from a hatchery on Long Island, New York. Juveniles were used rather than adults in order to maximize the number of individuals used per experiment, to reduce interference caused by gonadal proliferation and spawning, and because they are less prone to handling disturbance. Clams were acclimated to ca $17^{\circ} \mathrm{C}$ at ambient light levels in a flow-through system supplied with natural seawater supplemented with cultured Thalassiosira weissflogii for $3 \mathrm{wk}$ prior to experimentation, i.e. prior to exposure to Alexandrium spp. Individual clams averaged $26.1 \mathrm{~mm}(\mathrm{SE}=0.2 ; \mathrm{n}=$ 220 ) in shell length (mean tissue wet weight $=0.78 \mathrm{~g}$,

Table 1 Percent molar toxin composition $\left( \pm \mathrm{SE}_{\text {, standard }}\right.$ error) of high (GtCA29) and low (GtLi22) toxicity Alexandrium isolates. Toxin abbreviations as in Fig. 1 (in order of elution from HPLC column)

\begin{tabular}{|c|c|c|c|c|}
\hline \multirow[t]{2}{*}{ Toxin } & \multicolumn{2}{|c|}{$\begin{array}{c}\text { A. fundyense } \\
\text { GtCA29 }(n=16)\end{array}$} & \multicolumn{2}{|c|}{$\begin{array}{l}\text { A. tamarense } \\
\text { GtLI22 }(\mathrm{n}=12)\end{array}$} \\
\hline & Mean $(\%)$ & SE & Mean $(\%)$ & $\mathrm{SE}$ \\
\hline$C_{1+2}$ & 21.53 & $(1.58)$ & 92.95 & $(0.44)$ \\
\hline $\mathrm{GTX}_{4}$ & 7.18 & $(0.40)$ & 4.34 & $(0.50)$ \\
\hline $\operatorname{GTX}_{1}$ & 0.57 & $(0.19)$ & 0.52 & $(0.08)$ \\
\hline $\mathrm{GTX}_{3}$ & 37.27 & $(2.08)$ & 1.93 & $(0.16)$ \\
\hline $\mathrm{GTX}_{2}$ & 4.75 & $(0.42)$ & 0.23 & $(0.03)$ \\
\hline NeosTX & 9.74 & $(1.09)$ & 0.04 & $(0.02)$ \\
\hline STX & 18.94 & $(1.03)$ & 0 & \\
\hline $\begin{array}{l}\text { Total toxicity } \\
\text { fpg STXeg cell }\end{array}$ & $\begin{array}{l}96.46 \\
1^{-1}\end{array}$ & $(12.17)$ & 5.93 & $(0.46)$ \\
\hline
\end{tabular}

$\mathrm{SE}=0.03)$ in the experiment with isolate GtCA29, and $23.4 \mathrm{~mm}$ ( $\mathrm{SE}=0.2 ; \mathrm{n}=215$; tissue wet weight $=0.61 \mathrm{~g}$, $\mathrm{SE}=0.02$ ) in that with GtLI22.

Since clams readily ingested the low-toxicity isolate, they were exposed to a monospecific diet of GtLI22 (at a desired concentration of 150 cells $\mathrm{ml}^{-1}$ ) for $13 \mathrm{~d}$. This cell density was selected since previous work (Bricelj et al. 1990) demonstrated that it was sufficient to maximize cell ingestion in the mussel Mytilus edulis. During the depuration period, lasting $25 \mathrm{~d}$, clams were ex-

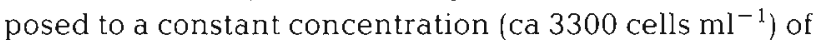
Thalassiosira weissflogii, equivalent to ca $455 \mu \mathrm{g}$ organic carbon $\mathrm{l}^{-1}$. This concentration is known to provide a nearly optimum food ration, i.e. one that maximizes rates of absorption and growth of hard clams (Malouf \& Bricelj 1989). All algal suspensions used in toxin uptake and detoxification experiments were made up in $0.22 \mu \mathrm{m}$ filtered seawater.

Preliminary short-term feeding trials indicated that clams stopped pumping and closed their valves in the presence of the high-toxicity Isolate GtCA29 unless stimulated with non-toxic algae. Therefore, in this experiment, clams were exposed to a mixed suspension of GtCA29 and Thalassiosira weissflogii. The 2 species were initially mixed in 50:50 cell volume equivalent proportions. From Day 7 of the $17 \mathrm{~d}$ intoxication experiment onwards, the proportion of GtCA29 was increased to $70 \%$ of the total cell volume (e.g. 105 GtCA cells $\mathrm{ml}^{-1}$ and $744 \mathrm{~T}$. weissflogii cells $\mathrm{ml}^{-1}$ ). On 2 occasions, during the first and second week of the experiment, the clams were offered only toxic dinoflagellate cells for 4 to $6 \mathrm{~h}$ to test their ability to acclimate to the toxic diet. During both attempts, the clams ceased their pumping activity until $T$. weissflogil was re-introduced in the suspension. As for the GtLI22 experiment, the clams were offered only diatom cells during the $18 \mathrm{~d}$ depuration period.

The experimental clams were held in a recirculating tank containing 361 of algal suspension prepared by dilution with filtered seawater $(0.22 \mu \mathrm{m})$ and held at $17^{\circ} \mathrm{C}$. The flow generated by the recirculating pump was sufficiently gentle to prevent any disruption of dinoflagellate cells. The experimental setup was the same as that previously described by Bricelj et al. (1990). Algae were continuously metered into the tank from a concentrated stock with a peristaltic pump, at a rate adjusted to yield an approximately constant cell density in the tank. Seawater in the tank was renewed at $2 \mathrm{~d}$ intervals.

Clams produced no pseudofeces within the range of experimental cell densities used. Therefore, over the 13 to $17 \mathrm{~d}$ experimental period, the number of dinoflagellate cells filtered (= ingested) was calculated twice a day, when the algal stock was replenished, by determining the difference between the number of cells 
delivered from the stock and the change in tank concentration. Preliminary experiments, in which algal densities were monitored over time with a Coulter Counter, showed that clams exhibited no differential retention efficiency or ingestion selectivity when offered a mixed suspension of GtCA29 and Thalassiosira weissflogii. Weight-standardized ingestion rate $\left(I_{s}\right)$ (cells $\mathrm{h}^{-1}$ ) for a standard-sized clam of $1 \mathrm{~g}$ wet tissue weight was calculated as: $I_{\mathrm{s}}=I_{\mathrm{e}} \times\left[W_{\mathrm{s}} / W_{\mathrm{e}}\right]^{0.75}$, where $I_{\mathrm{e}}$ and $W_{\mathrm{e}}$ are the experimental ingestion rate (cells $\mathrm{h}^{-1}$ ) and tissue wet weight $(\mathrm{g})$ per individual, $W_{\mathrm{s}}=1 \mathrm{~g}$ and 0.75 is the exponent $b$ of the allometric equation relating ingestion and body size $\left(I=a W^{b}\right.$; Bayne \& Newell 1983).

The clams' absorption efficiency (AE) of organic matter (OM) was determined only for individuals fed a monospecific diet of GtLI22, using Conover's (1966) ash-ratio method, as: $\mathrm{AE}=(1-[(\mathrm{Ash} / \mathrm{OM}$ in dinoflagellate cells)/(Ash/OM in feces)]) $\times 100$. Feces were collected immediately upon egestion, and algal and fecal samples were filtered onto precombusted, weighed Whatman $\mathrm{GF} / \mathrm{C}$ glass fiber filters rinsed with isotonic ammonium formate solution. Filters were dried at $85^{\circ} \mathrm{C}$ and dry and ashfree dry weights were determined with a Cahn electrobalance.

Toxin analysis. Clams ( $n=4$ to 9) were periodically removed for toxin analysis at ca $2 \mathrm{~d}$ intervals and replaced with new individuals which provided a duplicate time series (Series II). Clams were dissected into 2 tissue pools: visceral mass (including the digestive gland-stomach complex and gonadal follicles), and other tissues, comprising the foot, gills, adductor muscles, mantle, siphons; etc. The excised tissues were rinsed with distilled water and immediately frozen in liquid nitrogen for subsequent lyophilization. Dissection into 4 tissue pools - viscera, foot, adductor muscles and other tissues - was only undertaken on the last day of toxin uptake, to provide more detailed information on toxin localization.

Lyophilization of clam tissues after quick freezing was found empirically to yield more accurate and consistent toxin profiles than were obtained from samples stored as frozen whole tissue, particularly when the labile $\mathrm{N}$-sulfocarbamoyl derivatives were significant. Toxins from isolates GtCA29 and GtLI22 were extracted in $0.03 \mathrm{~N}$ acetic acid ( $\mathrm{pH} 3.5$ ), while tissues of clams fed these dinoflagellates were extracted in a $2: 1$ $\mathrm{v} / \mathrm{w}$ proportion of 0.03 to $0.1 \mathrm{NHOAc}$ (i.e. $2 \mathrm{ml} \mathrm{HOAC}$ per $g$ of wet tissue weight), following reconstitution of lyophilized tissues with distilled water. In general, $0.1 \mathrm{~N} \mathrm{HOAc}$ was found to be optimal for clam tissue extraction, preserving the more labile toxin derivatives but providing sufficient acidity to partially counteract the pH-buffering effect of the homogenized tissue (final pH 4.3).
Toxin analyses of dinoflagellate cultures (sampled on a daily basis) and clam tissues were performed by HPLC according to methods previously detailed by Boyer et al. (1986) and Bricelj et al. (1990) respectively. Individual PSP toxin components were quantified directly by comparison of relative chromatogram peak areas with standard reference toxins in a characterized mixture (MSPR-5) prepared from dinoflagellate cultures, and calibrated to primary standards. In order to correct for the presence of possible co-eluting fluorescent artifacts which might interfere with the direct quantitation of toxins $\mathrm{C}_{1+2}$, these toxins were converted to their respective carbamate analogues by hot acid hydrolysis. For dinoflagellate samples this treatment involved $5 \mathrm{~min}$ heating in $0.1 \mathrm{~N} \mathrm{HCl}$ at $100^{\circ} \mathrm{C}$ (Boyer et al. 1986$) ;>98 \%$ of the $\mathrm{C}_{1+2}$ toxin peak was accounted for by this method. For clam samples, where tissue buffering capacity is greater, this was often found to be inadequate to ensure complete toxin conversion. Tests performed with non-toxic tissue control samples of various tissues spiked with reference toxin indicated that the optimal treatment for complete $\mathrm{C}$-toxin conversion to gonyautoxins involved $10 \mathrm{~min}$ heating of small volumes $(<500 \mu \mathrm{l})$ of sample at $100^{\circ} \mathrm{C}$ in a $1: 1 \mathrm{v} / \mathrm{v}$ of $0.4 \mathrm{~N}$ $\mathrm{HCl}$. One or two samples from each tissue type, selected at representative stages of the experiment (early, mid and late contamination, and early and late detoxification) were also analysed by a gradient elution method (Sullivan 1990) specifically configured for the separation of the $C$-toxin components. No toxins $C_{3}$ or $\mathrm{C}_{4}$ (Fig. 1) were identified in any samples; the molar
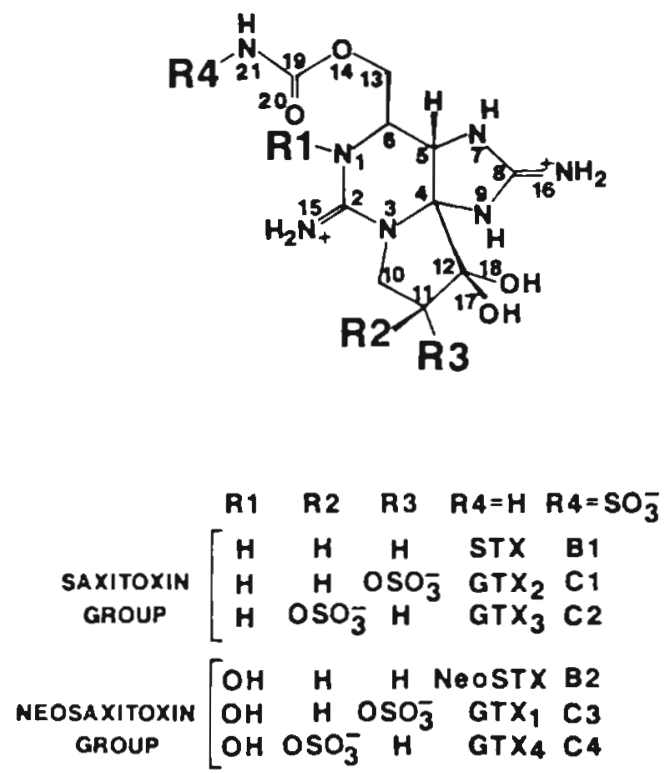

Fig. 1 Structural relationship among saxitoxin and various carbamate $(\mathrm{R} 4=\mathrm{H})$ and $\mathrm{N}$-sulfocarbamoyl $\left(\mathrm{R} 4=\mathrm{SO}_{3}^{-}\right)$ derivatives. STX: saxitoxin; neoSTX: neosaxitoxin; GTX $_{1,2,3,4}$ : gonyautoxins $1,2,3,4 ; C_{1}, B_{1.2}$ : N-sulfocarbamoyl toxins 
ratio of $C_{2} / C_{1}$ was rather unstable, but never $<15: 1$. Due to this facile epimerization, and the predominance of $\mathrm{C}_{2}$, the $\mathrm{C}$-toxin component is reported as the sum of $\mathrm{C}_{1+2}$. The analytical detection limits of the HPLC system (20 $\mu$ injection) for the individual toxin derivatives were as follows: $\mathrm{C}_{1+2}=0.54, \mathrm{GTX}_{1}=9.01, \mathrm{GTX}_{2}=$ 1.15, GTX $_{3}=0.95$, neoSTX $=12.31$ and STX $=8.94$ (in $\mu \mathrm{g}$ STXeq $100 \mathrm{~g}^{-1}$ shellfish tissue). Toxicity was calculated from published toxin-specific conversion factors of mouse units (MU)/ $4 \mathrm{~mol}$ of toxin (Boyer et al. 1986), assuming $0.18 \mu \mathrm{g}$ STXeq $\mathrm{MU}^{-1}$ (Shimizu 1978)

Statistical analyses to examine changes in toxin composition involved a preliminary comparison between toxin proportions (expressed as a \% of total toxicity in $\mu \mathrm{g}$ STXeq) in viscera and other tissues during both toxin uptake and detoxification ( $t$-test of the difference between 2 means using arcsine transformed data). Temporal changes in toxin profiles (dinoflagellate cells vs clams tissues during toxin uptake vs tissues during detoxification) were analyzed using ANOVA and planned comparisons of arcsine transformed data (Sokal \& Rohlf 1981), conducted separately on the 2 tissue pools. The following orthogonal comparisons were made: (1) algal cells vs clam tissues (uptake and detoxification), and (2) clam tissues during toxin uptake vs detoxification.

\section{RESULTS}

\section{Kinetics of toxin uptake and loss}

Concentrations of dinoflagellate cells actually measured in the experimental tank fluctuated around desired levels (Fig. 2), averaging 112 cells $\mathrm{ml}^{-1}$ for isolate GtLI22 and 159 cells $\mathrm{ml}^{-1}$ for isolate GtCA29 over the course of each experiment. Cell toxicity varied considerably, but toxin ratios remained fairly constant (Table 1).

Mercenaria mercenaria experienced no mortalities during acclimation or exposure to isolate GtLI22, and

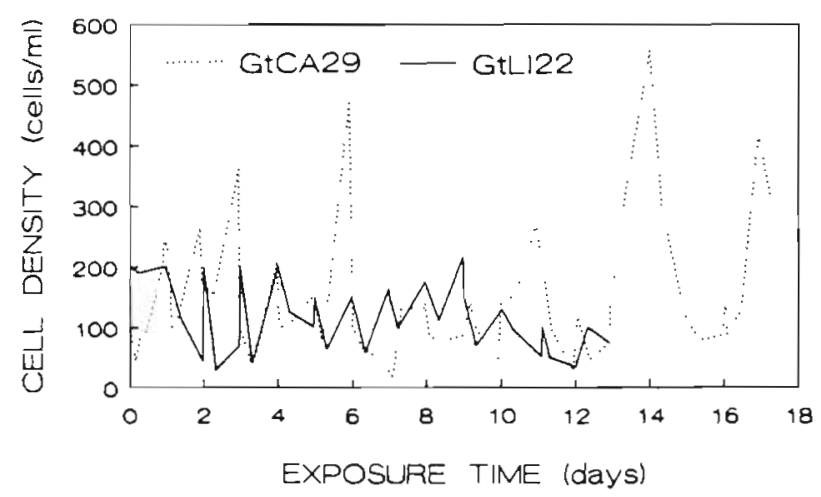

Fig. 2. Exposure concentration of Mercenaria mercenaria to Alexandrium spp. during experiments with GtCA29 and GtLI22 isolates only $3.4 \%$ mortality when offered the high-toxicity isolate $(6$ out of 8 clams died during the last $4 \mathrm{~d}$ of intoxication). Clams readily ingested the low-toxicity isolate GtLI22: ingestion rate remained constant throughout the experiment, and was significantly higher than that obtained for the more toxic isolate (Fig. 3). The inflection point in the linear curve of cumulative GtCA29 ingestion shown in Fig. 3 reflects the increase in relative contribution of this isolate from 50 to $70 \%$ of the total algal volume offered over the course of the experiment. The total amount of toxin in the dinoflagellate cells filtered by the clams is estimated from the product of cumulative weight-specific cell ingestion rate (ingestion/tissue weight) and cell toxicity. Thus, for clams exposed to GtLI22 cells the cumulative weight-specific toxin ingestion rate $(y)$ in $\mu \mathrm{g}$ STXeq (100 g wet tissue $\mathrm{wt})^{-1}$ (Fig. 4A) is given by:

$$
y=31.00(\mathrm{SE}=0.45) t_{i} \quad \mathrm{r}^{2}=0.98
$$

where $t=$ time (h). During the first week of exposure to isolate GtCA29, the toxin ingestion rate was indistinguishable from that of clams offered GtLI22. Thus, initially, the lower ingestion rate of GtCA29 cells was compensated for by this isolate's higher cell toxicity. After the first week of exposure to isolate GtCA29, toxin ingestion ( $y$; Fig. 4A) increased markedly, as described by the regression equation:

$$
\begin{gathered}
y=-21042.3(\mathrm{SE}=1718.6)+149.8(\mathrm{SE}=5.1) t \\
\mathrm{r}^{2}=0.98
\end{gathered}
$$

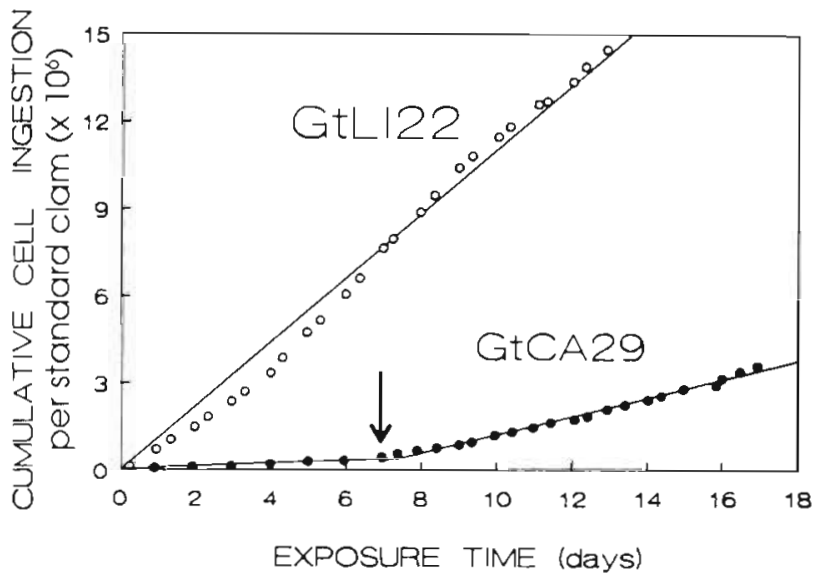

Fig. 3. Mercenaria mercenaria. Cumulative weight-standardized cell ingestion rate of Alexandrium spp. (for a standard clam $1 \mathrm{~g}$ in wet tissue weight). Clams were offered a monospecific diet of GtLI22; GtCA29 was offered in combination with Thalassiosira weissflogii larrow marks a change in the relative contribution of GtCA29 to total cell volume (see text)]. Fitted linear regressions: $y=46083(\mathrm{SE}=552) t ; \mathrm{r}^{2}=0.98$ (for GtLI22); $y=2582(\mathrm{SE}=104) t_{;} \mathrm{r}^{2}=0.96$ (for initial phase of exposure to GtCA29); and $y=-1.926 \times 10^{6}(\mathrm{SE}=88649)+$ $13207(\mathrm{SE}=285) t_{i} \mathrm{r}^{2}=0.99$ (for final phase of exposure to GtCA29, $t>177 \mathrm{~h})$, where $t=$ time $(\mathrm{h})$ 

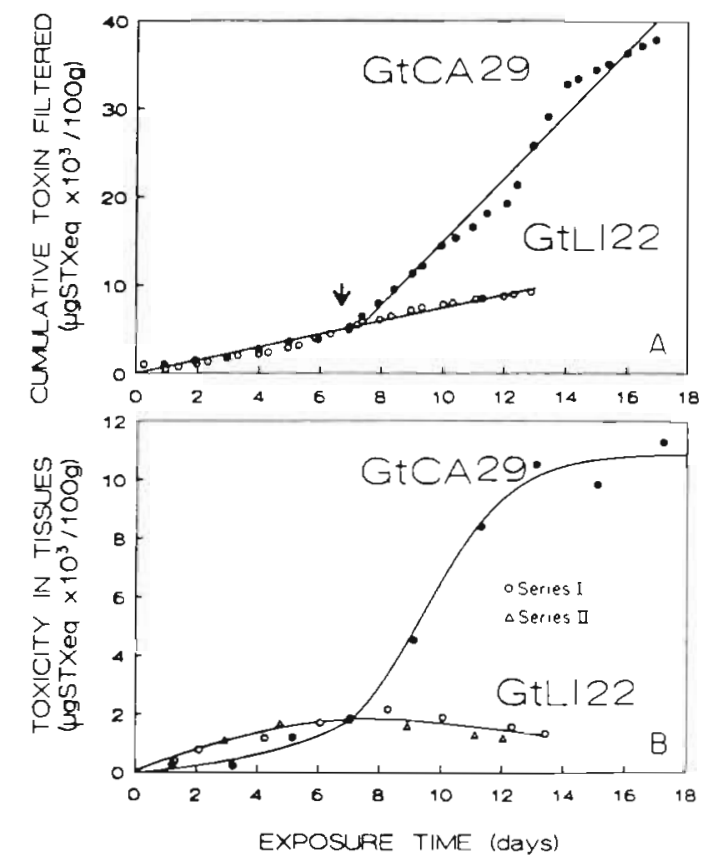

Fig. 4. Mercenaria mercenaria. (A) Cumulative weightspecific ingestion rate of PSP toxins from Alexandrium spp. (GtCA29 and GtLI22 isolates; arrow as in Fig. 3; see text for fitted regressions]. (B) Total toxicity of clam tissues [ $\mu \mathrm{g}$ STXeq $\left.(100 \mathrm{~g} \text { wet tissue } \mathrm{wt})^{-1}\right]$ during experimental toxin accumulation (curves fitted by eye)

This increase was accompanied by a sharp increase in the rate of incorporation of toxin in clam tissues (Fig. 4B). Weight-specific toxicity of whole tissues, in $\mu \mathrm{g}$ STXeq $100 \mathrm{~g}^{-1}$, is reported in Fig. 4 because this is the standard unit used by regulatory agencies, and thus allows direct comparison with published toxicity values.

Clams attained constant, saturation toxin levels within ca 13 d of exposure to GtCA29. Toxicities peaked at $10543 \mu \mathrm{g}$ STXeq $100 \mathrm{~g}^{-1}$ (mean of last 3 data points in Fig. 4B), compared to a maximum value of only $2150 \mu \mathrm{g}$ STXeq $100 \mathrm{~g}^{-1}$ reached after $8 \mathrm{~d}$ of exposure to isolate GtLI22. Both replicate time series with GtLI22 cells exhibited a 35 to $38 \%$ decline in toxicity of clam tissues during the last 5 to $6 \mathrm{~d}$ of toxin accumulation (Fig. 5). This may have resulted from a reduction in the mean cell toxicity of dinoflagellate cultures used over this period, which dropped to $4.2 \mathrm{pg} \mathrm{cell}^{-1}$, a value $32 \%$ below that obtained during the rest of the toxin uptake phase. Toxin uptake/detoxification curves obtained for the 2 isolates were asymmetrical, skewed to the left, especially for GtLI22, due to the fact that detoxification proceeded at a slower rate than toxin accumulation (Fig 5).

The efficiency of toxin incorporation into clam tissues can be estimated from the ratio [(Maximum toxin body

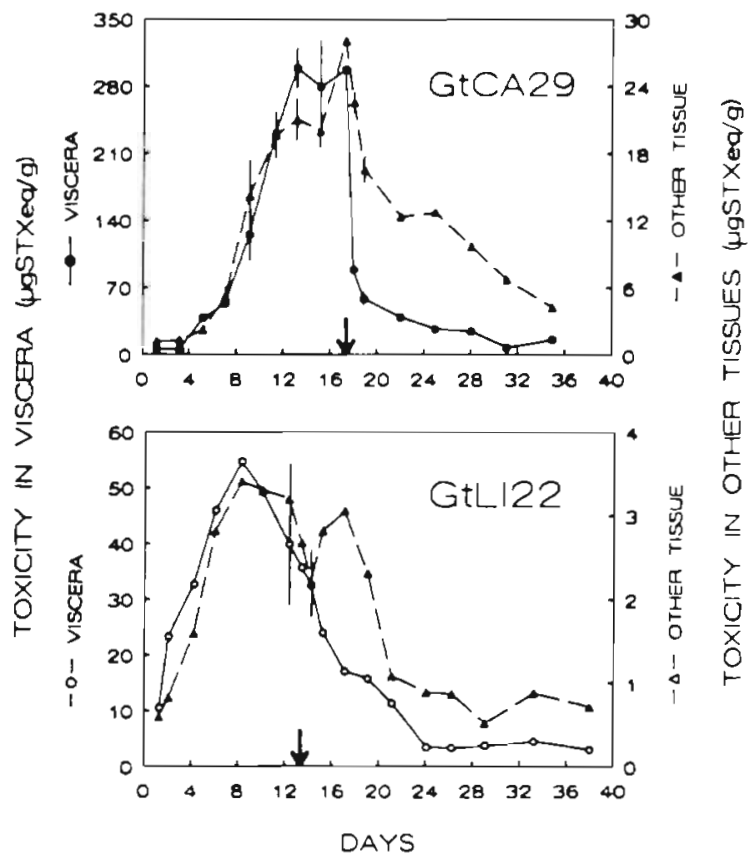

Fig. 5. Mercenaria mercenaria. Patterns of PSP toxin accumulation and loss ( $\mu \mathrm{g}$ STXeq $g$ wet tissue $\mathrm{wt}^{-1}$ ) in visceral mass and other tissues (only Series I shown). Arrow marks the start of detoxification. Error bars $= \pm \mathrm{SE}$ of 2 samples, each with pooled tissues from 4 to 9 clams

burden)/(Cumulative toxin ingested at the time when maximum toxicity is attained)] $\times 100$. Based on a cumulative toxin ingestion rate of $6169 \mu \mathrm{g}$ STXeq $100 \mathrm{~g}^{-1}$ (estimated from Eq. (1) at $t=199 \mathrm{~h}$ ), the toxin incorporation efficiency of clams (Series I) fed upon isolate GtLI22 equals $34.8 \%$. Similar calculations (at $t=314 \mathrm{~h}$ ) yield an efficiency of $40.4 \%$ for clams exposed to isolate GtCA29. Using Conover's (1966) ash-ratio method, clams were found to absorb $61.8 \%$ $(\mathrm{SE}=3.86)$ of the organic matter ingested when fed a monospecific diet of GtLI22 at ca 100 cells $\mathrm{ml}^{-1}$.

Detoxification rates of whole clams are adequately described by the general exponential equation $T_{t}=$ $T_{0} \mathrm{e}^{-i \mathrm{i}}$, which becomes:

$\ln T_{t}=8.192-0.098 t_{;} \quad r^{2}=0.82$ (for GtCA29) (3) and $\ln T_{t}=7.000-0.100 t_{i} \quad \mathrm{r}^{2}=0.83$ (for GtLI22) (4) where $t=$ detoxification period $(\mathrm{d})_{i} T_{t}=$ toxicity [ $\mu \mathrm{g}$ STXeq $\left.(100 \mathrm{~g} \text { wet tissue } \mathrm{wt})^{-1}\right]$; and the slopes represent the toxin decay coefficients $\lambda$. Clams exposed to GtCA29 lost $60 \%$ of their body burden of toxin within $18 \mathrm{~h}$ after the beginning of the detoxification period. This initial, rapid toxin loss, which was not observed in clams exposed to isolate GtLI22, was followed by a second phase of slower detoxification. Thus for GtCA29, Eq. (3) describes the kinetics of toxin release only during the latter phase $\left(T_{0}=18 \mathrm{~h}\right)$. 


\section{Tissue compartmentalization of toxin}

Relative contributions of viscera and other tissues to the total body burden of toxin during toxin uptake and loss are shown in Fig. 6. The viscera comprised on average 32.0 and $28.7 \%$ of total tissue wet weight of clams in the GtLI22 and GtCA29 experiments, respectively, while contributing $>78 \%$ of total toxicity during toxin incorporation. For example, the viscera of clams exposed to isolate GtLI22 contributed $89.0 \%$ ( $\mathrm{SE}=0.8$ Series I) and $86.0 \%$ (SE $=2.4$, Series II) to the total body burden of toxin. This relative contribution declined steadily during detoxification, dropping to $62.8 \%$ of total toxicity by the end of the experiment (Fig. 6). A similar pattern in the partitioning of toxins between tissues was observed in clams exposed to GtCA29, except for 2 anomalously low values recorded at the beginning of uptake in Series I clams (Fig. 6). Over the same sampling period ( 1 to $4 \mathrm{~d}$ ) the viscera of Series II clams accounted for up to between 74 and $78 \%$ of total toxin. During detoxification the viscera contributed on average $51.6 \%$ of the total toxin body burden.

The viscera thus attained maximum toxicities about an order of magnitude greater than those in remaining tissues (Fig. 5). In the GtCA29 experiment, toxicities of viscera and other tissues peaked at 305.2 ( $\mathrm{SE}=42.2$ ) and 31.5 (SE $=4.3) \mu \mathrm{g} \mathrm{STXeq} \mathrm{g}^{-1}$, respectively (average of Series I and II). When remaining tissues were further separated into foot, adductor muscles and gill/mantle/siphons, maximum toxin concentrations attained in these tissue compartments were 12.9.15.2

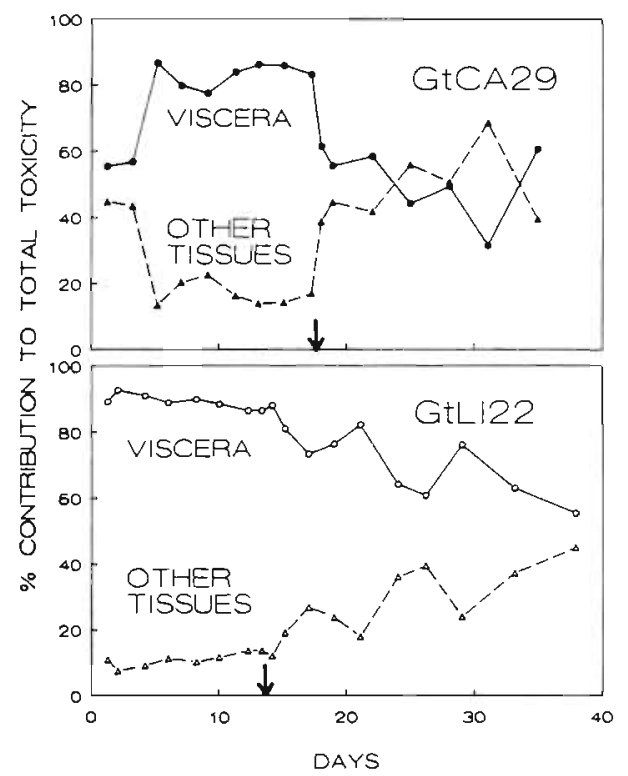

Fig. 6. Mercenaria mercenaria. Percent relative contribution of viscera and other tissues to total body burden of toxin during uptake and elimination of PSP toxins accumulated from GtCA29 and GtLI22 isolates (arrow as in Fig. 5; only Series I shown) and $31.5 \mu \mathrm{g}$ STXeq $\mathrm{g}^{-1}$, respectively. The viscera detoxified faster ( $70 \%$ toxin loss in $18 \mathrm{~h}$ ) during the first day of depuration than other tissues ( $2 \%$ loss in $18 \mathrm{~h}$ ), at least partially reflecting the loss of PSP toxins through gut evacuation. Numerous intact dinoflagellate cells were observed in feces of clams fed either of the 2 isolates. Nevertheless, even after a 3 wk detoxification period, toxicities of viscera and other tissues remained 15 and $5.3 \times$ above the regulatory level for shellfish closure (80 $\mu \mathrm{g}$ STXeq $100 \mathrm{~g}^{-1}$ ), respectively (Fig. 5).

Clams exposed to GtLI22 attained maximum toxicities of $54.5(\mathrm{SE}=0.1)$ in viscera and $3.70(\mathrm{SE}=0.3)$ $\mu \mathrm{g} \mathrm{STXeq} \mathrm{g}^{-1}$ in other tissues (mean of Series I and II). At the end of the toxin accumulation phase, the foot and adductor muscles yielded toxin levels $3 \times$ lower (1.3 and $1.5 \mu \mathrm{g} \mathrm{STXeq} \mathrm{g}^{-1}$ ) than the gill/mantle/siphons (4.4 $\mu \mathrm{g}$ STXeq $\mathrm{g}^{-1}$ ). Maximum toxicities in the viscera declined by 34.7 to $46.8 \%$ during the last $5 \mathrm{~d}$ of toxin uptake in clams exposed to isolate GtLI22 in both replicate time series, whereas a gradual decline in toxin levels prior to the detoxification phase was not observed in other tissues (Fig. 5). After $25 \mathrm{~d}$ of detoxification, toxin levels in both viscera and other tissues continued to exceed the regulatory level and would be considered unfit for human consumption. Thus, with both dinoflagellate isolates, although the viscera attained peak toxicities 10 to $20 \times$ greater than other tissues, they were only $2.8 \times$ as toxic by the end of the 3 wk detoxification period.

\section{Toxin composition}

Figs. 7 \& 8 compare the toxin composition between dinoflagellate cells and clam tissues over the course of toxin uptake and loss; results of the statistical analysis are given in Table 2. With both isolates, significant differences (Student's $t$-test) in toxin composition were detected between viscera and other tissues during toxin uptake; these differences became less pronounced (GtLI22 experiment) or negligible (GtCA29 experiment) during detoxification. These results provided justification for analyzing temporal changes separately in the 2 tissue compartments.

Mean toxin proportions estimated for the toxin accumulation phase include only those values obtained once clams attained peak toxicities (last 4 to $5 \mathrm{~d}$ of toxin uptake), while mean values during detoxification are represented only for the initial phase (first $10 \mathrm{~d}$ ) (Fig. 7 . Table 2). Initial contamination and later detoxification values were excluded from statistical analysis because the poor precision and accuracy of analytical values of GTX $_{1+4}$ at low levels of these toxins may introduce bias into the calculation of relative toxicity. Less reliable detection of $\mathrm{GTX}_{1+4}$ at low levels occurs because these compounds, though highly toxic, form only weakly 


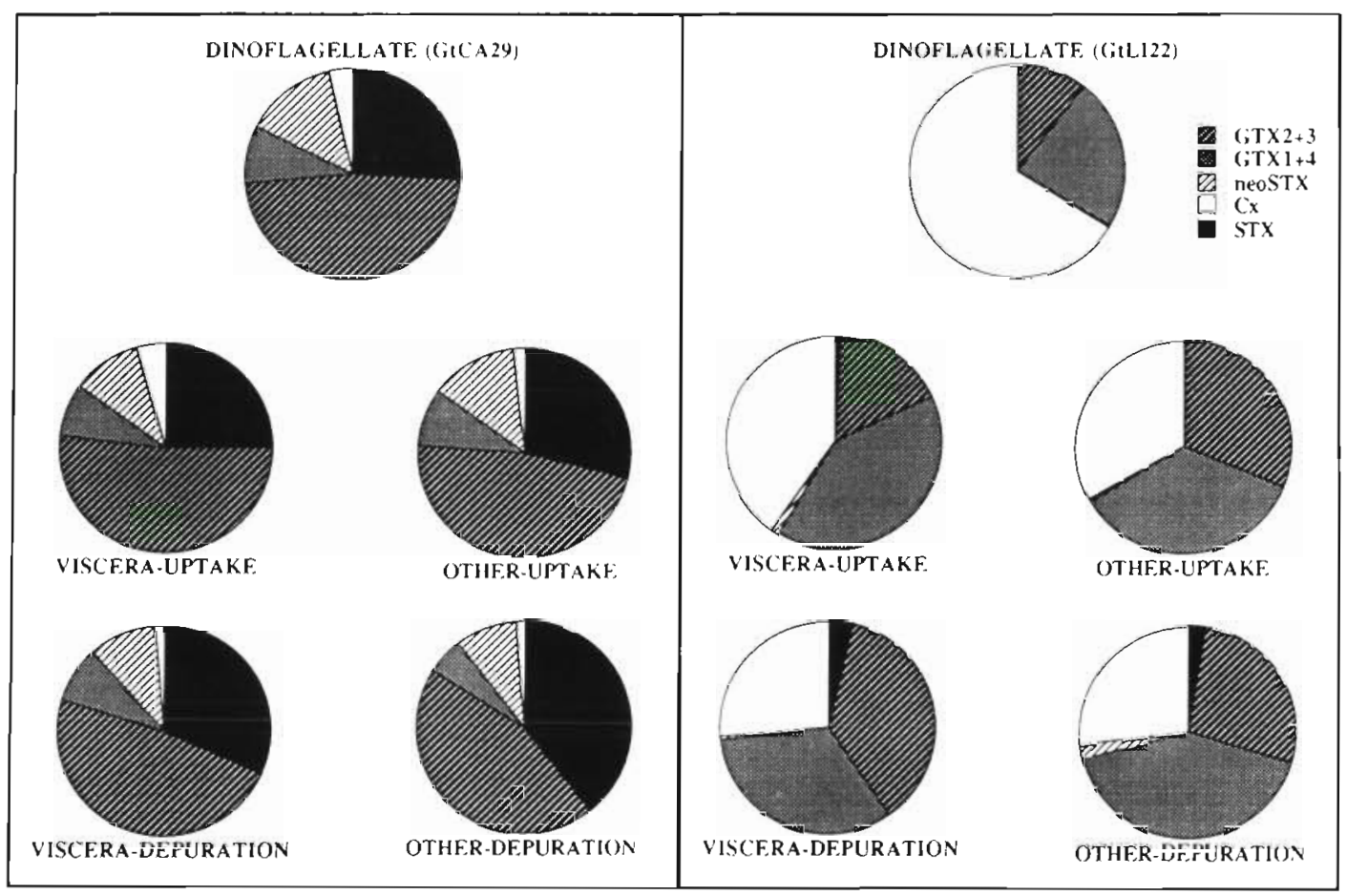

Fig. 7. Composition of individual PSP toxins (as \% of total toxicity in $\mu$ g STXeq) in dinoflagellate cells ( $\mathrm{n}=12$ to 16 ), and Mercenaria mercenaria viscera and other tissues (Series I \& II combined) during toxin uptake ( $\mathrm{n}=5$ to 8 ), and initial detoxification phase ( $\mathrm{n}=5$ to 6 ; see Table 2) (tissue-phase indicated below each pie chart)

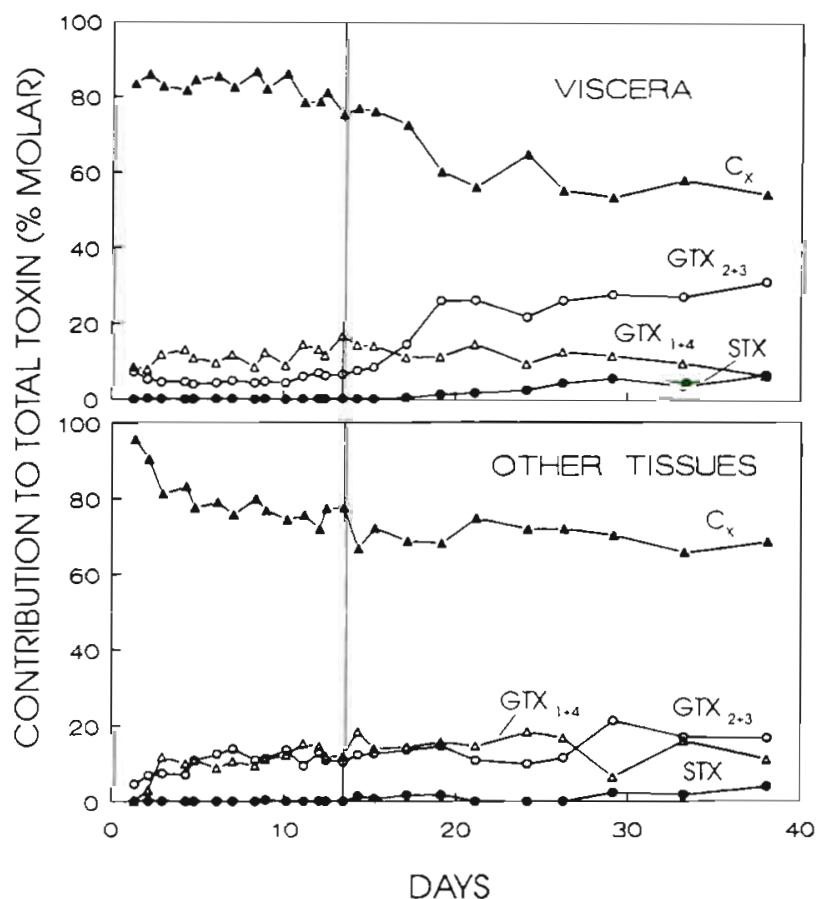

Fig. 8. Mercenaria mercenaria. Percent contribution of individual toxins to total toxin, calculated on the basis of molar concentrations, in viscera and other tissues of clams exposed to GtLI22 (Series I \& II combined). Toxin abbreviations as in

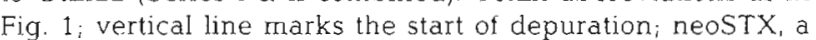
minor constituent, is not shown fluorescing derivatives. Complete time series of toxin proportions are shown in Fig. 8 for clams fed upon GtLI22, since temporal changes in toxin composition were more pronounced with this isolate.

In general, differences in toxin profiles between tissues and dinoflagellate cells were greater when GtLI22, the strain rich in N-sulfocarbamoyl toxins $\left(C_{1+2}\right)$, was used as a food source. Highly significant differences in all toxin proportions $(p<0.001)$ were found between GtLI22 cells and both tissue pools (Table 2). For example, the relative contribution of toxins $C_{1+2}$ dropped from $66 \%$ of total toxin in GtLI22 to only 26 to $27 \%$ in all clam tissues during detoxification. Toxin loss in viscera was accompanied by a significant reduction in the proportion of $\mathrm{C}_{1+2}$, and a parallel increase in $\mathrm{GTX}_{2+3}$ (at $\mathrm{p}<0.001$ ). In this tissue pool, the shift in the relative contributions of $\mathrm{C}_{1+2}$ and $\mathrm{GTX}_{2+3}$ occurred most rapidly during early detoxification (Fig. 8). Evidence of differential net elimination of individual toxins can also be drawn from comparisons of decay coefficients for each toxin during detoxification. Thus, while the exponential decline in absolute concentrations of $\mathrm{C}_{1+2}$ and $\mathrm{GTX}_{1+4}$ occurred at similar rates $(\lambda=-0.14$ and -0.15 respectively), this coefficient was significantly lower $(\lambda=$ -0.08 ) for $\mathrm{GTX}_{2+3}$.

In other tissues, the contribution of $\mathrm{C}_{\mathrm{i}+2}$ also declined significantly $(p<0.01)$ over time, but at a slower rate 
Table 2. Alexandrium isolates and Mercenaria mercenaria. Mean relative toxin composition (as \% of total toxin, $\pm \mathrm{SE}$ ) in dinoflagellate cells and clam tissues during toxin uptake and detoxification with GtCA29 and GtLI22. Toxin abbreviations as in Fig. 1; neoSTX not shown for GtLI22 since it constitutes $<1 \%$ of total toxins. Means connected by a line are not significantly different or marginally significant $(p<0.05)$ as determined from ANOVA planned comparisons test (see 'Methods'); those not connected are significantly different at $p<0.01$ or 0.001 nd: not detectable

\begin{tabular}{|c|c|c|c|c|c|}
\hline \multicolumn{6}{|c|}{ Clams exposed to GtLI22: } \\
\hline Toxin & Uptake & Detoxification & GtLI22 & Uptake & Detoxification \\
\hline$C_{1+2}$ & $33.2(1.0)$ & $27.0(1.2)$ & $66.2(1.4)$ & $40.4(2.2)$ & $26.2(2.8)$ \\
\hline STX & $0.2(0.2)$ & $2.6(1.0)$ & nd & $0.8(0.1)$ & $3.7(1.2)$ \\
\hline $\mathrm{GTX}_{1+4}$ & $35.2(1.6)$ & $41.2(2.0)$ & $23.1(1.8)$ & $40.5(1.8)$ & $32.9(3.2)$ \\
\hline $\mathrm{GTX}_{2+3}$ & $30.9(1.4)$ & $27.1(1.2)$ & $10.5(0.9)$ & $17.3(0.6)$ & $\underline{36.6(5.0)}$ \\
\hline \multicolumn{6}{|c|}{ Clams exposed to GtCA29: } \\
\hline \multirow[t]{2}{*}{ Toxin } & \multicolumn{2}{|c|}{ Other tissues } & \multirow[t]{2}{*}{ GtCA29 } & \multicolumn{2}{|c|}{ Viscera } \\
\hline & Uptake & Detoxification & & Uptake & Detoxification \\
\hline $\mathrm{C}_{1+2}$ & $1.8(0.1)$ & $0.9(0.1)$ & $3.7(0.1)$ & $3.9(0.3)$ & $1.3(0.2)$ \\
\hline STX & $30.2(1.9)$ & $39.5(6.1)$ & $25.8(0.3)$ & $25.4(0.9)$ & $31.7(5.1)$ \\
\hline neosTX & $12.6(1.4)$ & $9.5(1.0)$ & $13.8(0.4)$ & $12.2(1.9)$ & $10.3(1.5)$ \\
\hline $\mathrm{GTX}_{1+4}$ & $9.3(0.7)$ & $5.5(2.5)$ & $8.9(0.2)$ & $9.6(1.6)$ & $8.6(3.0)$ \\
\hline $\mathrm{GTX}_{2+3}$ & $46.0(2.0)$ & $44.6(3.4)$ & $47.8(0.5)$ & $49.6(2.5)$ & $48.0(1.0)$ \\
\hline
\end{tabular}

than in viscera. The maximal decline in other tissues occurred earlier in the experiment, during intoxication. It is noteworthy that although STX was not detected in the GtLI22 clone, a low and relatively constant concentration of this toxin was present in clam tissues throughout the experiment (averaging $0.4 \mu \mathrm{g} \mathrm{g}^{-1}$ in viscera).

In contrast, toxin profiles of GtCA29 cells closely resembled those of viscera made toxic with this strain. The proportion of $\mathrm{C}_{1+2}$ also declined significantly $(\mathrm{p}<0.001)$ in this tissue pool during detoxification (Table 2). Furthermore, other tissues contained significantly higher proportions of STX $(p<0.01)$ and lower proportions of $\mathrm{C}_{1+2}(\mathrm{p}<0.001)$ than GtCA29 cells. STX increased from $26 \%$ in dinoflagellate cells to $40 \%$ in other tissues during detoxification.

Rapid epimerization of gonyautoxins, evidenced by the decline in the molar epimer ratio of $\mathrm{GTX}_{3} / \mathrm{GTX}_{2}$, occurred in clam tissues during toxin uptake, and continued at a much slower rate during detoxification (Fig. 9). Similar rates of exponential decrease in the $\mathrm{GTX}_{3} / \mathrm{GTX}_{2}$ ratio were observed in both tissue pools; therefore data for viscera and other tissues were combined for analyses. In dinoflagellate cells, the $\mathrm{GTX}_{3} /$ $\mathrm{GTX}_{2}$ epimer ratio was $9.0(\mathrm{SE}=1.1)$ and $8.8(\mathrm{SE}=0.9)$ for GtLI22 and GtCA29 respectively, but dropped to 1.2 and 0.9 in clam tissues during detoxification.

\section{DISCUSSION}

This study clearly demonstrates that Mercenaria mercenaria, previously reported to remain non-toxic during toxic blooms of Alexandrium spp., can become highly toxic in the presence of both low and high-toxicity isolates. Critical parameters characterizing toxin uptake and loss in this species relative to dinoflagellate toxicity are summarized in Table 3 . Clams attained the regulatory toxin level for shellfish closure within only 5 to $7 \mathrm{~h}$ of feeding on toxic dinoflagellates, and toxicities peaked at levels well in excess of this threshold after 1 to 2 wk of exposure. Although clams ingested GtCA29 at a significantly lower rate than the less toxic isolate, they ultimately acquired a body burden of toxin $5 \times$ greater than individuals fed upon isolate GtLI22. Continued pumping activity and ingestion of a highly toxic strain such as GtCA29, however, appear to require the presence of a non-toxic algal stimulant in the water column. Thus, although $M$. mercenaria nerve fibers are resistant to PSP toxins (Twarog et al. 1972), whole organisms are nonetheless capable of behavioral avoidance of highly toxic cells, perhaps mediated by a toxin recognition mechanism.

A reduction in grazing rates with increasing toxin level of Alexandrium spp. has been described in copepods (Ives 1985, 1987) and in the ciliate Favella 


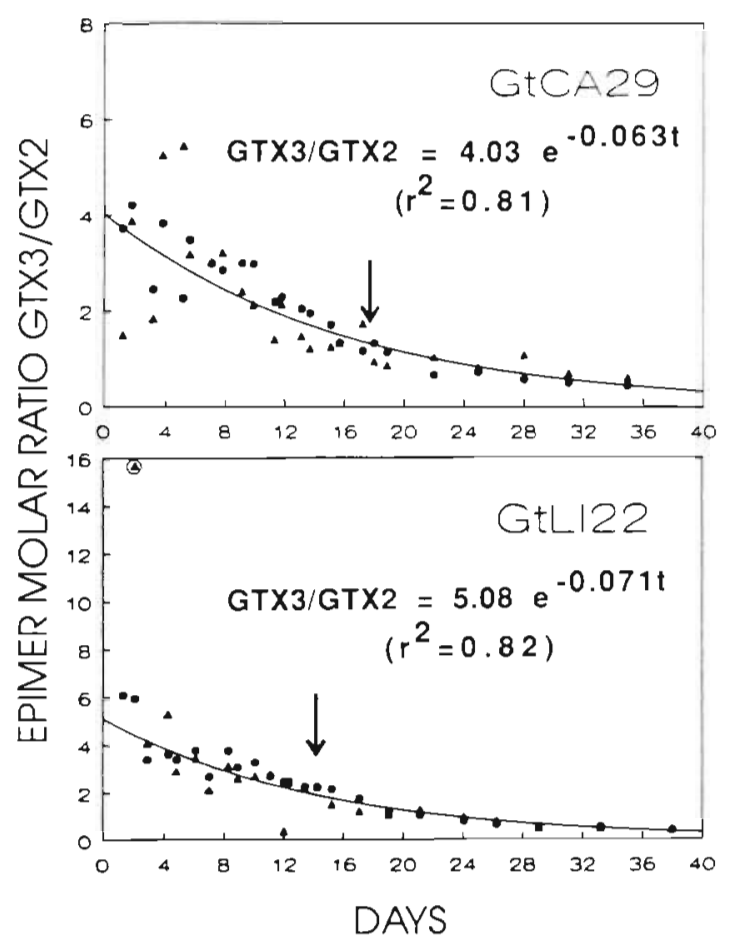

Fig. 9. Mercenaria mercenaria. Epimer molar ratio of $\beta$ to $\alpha$ gonyautoxins $\left(\mathrm{GTX}_{3} / \mathrm{GTX}_{2}\right)$ in clam tissues (viscera and other tissues) during uptake and elimination of toxins derived from isolates GtCA29 and GtLI22 (both Series I \& II are included). Arrows mark the start of depuration; ( 4 ) other tissues; (•) viscera. Curves were fitted to the data using the equations shown above (circled outlier was excluded from analysis)

ehrenbergii (Hansen 1989), and was attributed to progressive physiological incapacitation upon initial ingestion of toxic cells (Ives 1987). Further research is necessary to determine whether pre-or post-ingestive mechanisms, i.e. chemosensory detection or physiological incapacitation, are involved in toxin recognition by Mercenaria mercenaria. The minimum level of 'background noise', in the form of non-toxic algal supplement, required to induce grazing on highly toxic cells should also be established. Clams showed no evidence of decreasing their ingestion of toxic cells with increasing body burden of toxin. The differential response of M. mercenaria to the 2 isolates used in this study may thus result from differences between carbamate and $N$ sulfocarbamoyl toxins in their sodium channel binding properties, rather than differences in toxin levels per se. Alternatively, clams may be able to sequester toxins in such a way that an increasing body burden does not disrupt function of the whole organism.

Our findings suggest that, during toxic blooms, the rapid increase in Alexandrium cell densities, and their dominance over other phytoplankton species, may preclude hard clams from accumulating significant toxin levels particularly in northern latitudes, where highly toxic populations are prevalent. The risk of substantial
Table 3. Mercenaria mercenaria. Main parameters characterizing the kinetics of PSP toxin uptake and loss in clams exposed to isolates GtLI22 and GtCA29. RL: regulatory level for shellfish closure $=80 \mu \mathrm{g}$ STXeq $100 \mathrm{~g}^{-1} ;$ I \& II = Series I \& II (see 'Methods'). Toxin half-life is defined as the time required to reduce tissue toxin levels to $50 \%$ of initial levels

\begin{tabular}{|c|c|c|}
\hline & GtLI22 & GtCA29 \\
\hline $\begin{array}{l}\text { Wt.-standardized ingestion } \\
\text { rate }^{a}\left(\text { cells } \mathrm{g}^{-1} \mathrm{~d}^{-1} \times 10^{5}\right)\end{array}$ & 11.06 & $3.18^{\mathrm{b}}$ \\
\hline $\begin{array}{l}\text { Exposure time to attain } \\
\operatorname{RL}(\mathrm{h})^{c}\end{array}$ & $\begin{array}{l}7 \text { (I) } \\
5 \text { (II) }\end{array}$ & 9 \\
\hline $\begin{array}{l}\text { Maximum toxicity } \\
\left(\mu \mathrm{g} \text { STXeq } 100 \mathrm{~g}^{-1}\right)\end{array}$ & $\begin{array}{l}2150 \text { (I) } \\
1810(\text { II })\end{array}$ & 10543 \\
\hline $\begin{array}{l}\text { Toxin incorporation } \\
\text { efficiency }(\%)\end{array}$ & 35 & 40 \\
\hline Toxin half-life (d) & $7^{\mathrm{d}}$ & $0.6^{e}$ \\
\hline Time to detoxify to RL (d) & $24^{\mathrm{d}}$ & $43^{1}$ \\
\hline \multicolumn{3}{|c|}{ 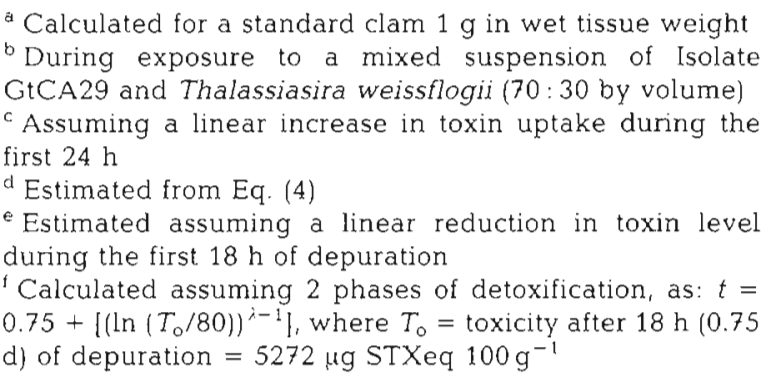 } \\
\hline
\end{tabular}

PSP toxin accumulation by Mercenaria mercenaria may actually be reduced under conditions where Alexandrium blooms are essentially monospecific, highly toxic on a per cell basis, and at high cell densities, due to short-term cessation of filtration activity. For example, along coastal regions of the estuary and Gulf of St. Lawrence, at the northern extreme range of $M$. mercenaria, it is not uncommon for hydrodynamic factors to

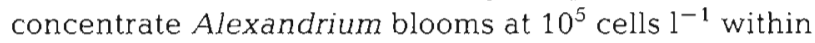
2 tidal cycles, with cell toxicities of $>100 \mathrm{pg}$ STXeq cell $^{-1}$, but blooms are rarely persistent (Cembella \& Therriault 1989). The present research also indicates that the historical absence of PSP-contaminated hard clams in Long Island coastal waters may more likely be attributed to the typically low densities of Alexandrium encountered at its southern limit of distribution (generally $<10^{4}$ cells $1^{-1}$ (Schrey et al. 1984)], rather than to the low toxicity of southern isolates. Since M. mercenaria attained toxin levels $24 \times$ above the regulatory level by ingesting a monospecific diet of isolate GtLI22 from Long Island, this suggests that the presence of such weakly toxic ecotypes in Long Island estuaries could pose a serious threat to the hard clam fishery under conditions allowing development of persistent bloom concentrations $\left(10^{5}\right.$ cells $\left.l^{-1}\right)$. This is especially 
true in view of the postulated trend of intensification and southward spreading of toxic Alexandrium blooms along the Atlantic coast of North America (Anderson 1989, Hayhome et al. 1989).

It is instructive to compare toxin uptake in Mercenaria mercenaria exposed to GtCA29 with that of the blue mussel Mytilus edulis contaminated with the same isolate under similar experimental conditions (Bricelj et al. 1990). Clams attained $10.5 \times 10^{3} \mu \mathrm{g}$ STXeq $100 \mathrm{~g}^{-1}$ within $13 \mathrm{~d}$, whereas saturation levels attained by $M$. edulis within the same time were $4 \times$ higher, at $45 \times 10^{3}$ $\mu \mathrm{g}$ STXeq $100 \mathrm{~g}^{-1}$. Lower toxicities in hard clams reflect their 3-fold lower weight-normalized cell ingestion rate $\left(3.2 \times 10^{5}\right.$ vs $10.1 \times 10^{5}$ cells g ${ }^{-1} \mathrm{~d}^{-1}$ in M. mercenaria and $M$. edulis, respectively). Large interspecific differences of up to an order of magnitude in ingestion rate of Alexandrium spp. (= Protogonyaulax tamarensis) were previously reported among 4 experimentally contaminated bivalve species (Lassus et al. 1989). Toxin incorporation efficiency in $M$. mercenaria was one half of that in $M$. edulis [= $79 \%$ (Bricelj et al. 1990)]. Absorption efficiency of organic matter $(62 \%)$ in $M$. mercenaria fed upon isolate GtLI22 was substantially greater than toxin incorporation efficiency $(35 \%)$, indicating that organic carbon and toxin budgets are not equivalent in this species.

We calculated that hard clams are able to detoxify to acceptable levels for human consumption $(<80 \mu \mathrm{g}$ STXeq $100 \mathrm{~g}^{-1}$ within ca 3 to $6 \mathrm{wk}$ ) (Table 3). Thus Mercenaria mercenaria ( $F$. Veneridae) appears to release toxins incorporated into various tissues fairly rapidly compared to other clam species, such as the venerid clam Saxidomus giganteus (Quayle 1969, Madenwald 1985) and mactrid clam Spisula solidissima (Blogoslawski \& Stewart 1978), which retain toxins at levels exceeding the acceptable regulatory limit for periods of several months to years. Rates of detoxification estimated for hard clams are comparable to those of contaminated field populations of Mytilus edulis ranging in maximum toxicities from 250 to $2500 \mu \mathrm{g}$ STXeq $100 \mathrm{~g}^{-1}$, where 2 to $8 \mathrm{wk}$ was sufficient for toxin levels to drop to the regulatory limit (calculated from data reviewed by Shumway 1990a). They are also comparable to those of softshell clams Mya arenaria, which detoxify to the closure level within 1 to $4 \mathrm{wk}$ (Hurst \& Gilfillan 1977).

Clams offered the more toxic strain detoxified faster than those exposed to GtLI22, as reflected in a shorter half-life, but took longer to detoxify to the quarantine level (Table 3). It thus appears that the rate of detoxification may be correlated with peak toxicity. An exponential relationship between the time required to detoxify to the regulatory level and maximum toxin body burden was described in field-contaminated mussels and softshell clams (Hurst \& Gilfillan 1977). Mytilus edulis and Mya arenaria were found to differ significantly in their mean toxin decay coefficients $(\lambda=-0.17$ and -0.10 respectively). The latter value is in remarkably good agreement with a decay coefficient of -0.10 estimated in this study (Eq. 4) for Mercenaria mercenaria contaminated with GtLI22 under laboratory conditions.

Little is known regarding the influence of temperature on toxin kinetics. Experiments described in this study were conducted at a constant temperature of $17^{\circ} \mathrm{C}$. This is representative of temperatures occurring in Long Island estuaries in late spring $\left(17\right.$ to $\left.21^{\circ} \mathrm{C}\right)$, when populations of Alexandrium attain maximum densities (Schrey et al. 1984). Unlike Mytilus edulis, however, in which clearance rate is independent of acclimation temperatures between 10 and $20^{\circ} \mathrm{C}$ (Bayne et al. 1977), Mercenaria mercenaria exhibits an increase in clearance with increasing acclimation temperature between 12 and $25^{\circ} \mathrm{C}\left(Q_{10}=1.4\right.$ to 1.8 ; Malouf \& Bricelj 1989). Therefore, it is possible that higher rates of toxin accumulation and detoxification than those reported in this study may occur at higher temperatures. In butter clams Saxidomus giganteus, the rate of detoxification was not enhanced by an increase in temperature from 7.5 to $16.5^{\circ} \mathrm{C}$ (Madenwald 1985), but strong binding of toxins is characteristic of this species.

During exposure of hard clams to toxic dinoflagellate cells, most $(>78 \%)$ of the toxin was localized in the visceral mass. This confirms earlier observations in Mytilus edulis (Bricelj et al. 1990) and in Mya arenaria during a natural bloom of Alexandrium (Martin et al. 1990), in which the viscera concentrated $96 \%$ and $80 \%$ of the total toxin body burden, respectively, at the toxicity peak. During detoxification, however, toxin concentrations (in $\mu \mathrm{g} \mathrm{g}^{-1}$ ) in viscera, which initially exceeded those in other tissues by an order of magnitude, rapidly approached levels found in other tissues. This converging pattern (illustrated in Figs. 5 \& 6), demonstrates that detoxification proceeds at a faster rate in viscera than in remaining tissues. In this study, the adductor muscles and muscular foot yielded the lowest toxin concentrations. The adductor muscle has been found to be least effective in concentrating toxins in bivalve species, e.g. M. arenaria (Martin et al. 1990), Spisula solidissima (Blogoslawski \& Stewart 1978), and placopecten magellanicus (Shimizu \& Yoshioka 1981).

\section{Toxin composition}

The toxin composition of ingested dinoflagellate cells may undergo changes in the tissues of a consuming organism due to $\mathrm{pH}$-mediated or metabolic transformation and/or selective retention of toxins. Enzymatic conversion of gonyautoxins and neoSTX to STX, 
through removal of the 11-hydroxysulfate and N-1 hydroxyl groups, was documented in the scallop Placopecten magellanicus (Shimizu \& Yoshioka 1981). Enzymatic decarbamoylation of toxins, through cleavage of the carbamate or sulfamate sidechain, was confirmed in the littleneck clam Protothaca staminea (Sullivan et al. 1983).

In our study, rapid differential elimination of C-toxins was observed in hard clams fed upon both isolates. In the GtLI22 experiment, the relative decline in $\mathrm{C}_{1+2}$ was paralleled by a significant enrichment in $\mathrm{GTX}_{2+3}$, and this shift in toxin proportions occurred more rapidly in viscera than in other tissues (Fig. 8). Since $C_{1}$ and $C_{2}$ can be readily hydrolyzed in vitro under acidic condi-

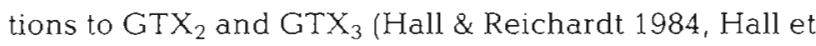
al. 1990), this reciprocal pattern argues strongly for the possibility of in vivo bioconversion of $\mathrm{N}$-sulfocarbamoyl toxins to gonyautoxins. The apparent higher proportion of toxin $\mathrm{C}_{1+2}$ in other clam tissues than in isolate GtLi22 for the first 2 time points (Fig. 8) is most likely due to imprecision in quantifying the toxins (especially $\mathrm{GTX}_{1+4}$ ) at low concentrations.

Conversion of $\mathrm{N}$-sulfocarbamoyl toxins to their corresponding decarbamoyl derivatives in the venerid clam Protothaca staminea was also found to occur more rapidly in viscera than in the mantle, muscle and siphon homogenates (Sullivan et al. 1983). The rapid conversion of less potent but more labile C-toxins to more potent carbamate toxins in hard clam viscera suggests a possible explanation for the slower initial detoxification rates of viscera in clams offered Isolate GtLI22 than in those offered GtCA29 (Fig. 5). Rapid differential elimination of $\mathrm{C}_{1+2}$ toxins over $5 \mathrm{~d}$, accompanied by an increase in the relative concentrations of neoSTX and to a lesser extent $\mathrm{GTX}_{2+3}$, was reported in the scallop Patinopecten yessoensis, following exposure to a natural bloom of Alexandrium catenella in which $C_{2}$ was the dominant toxin (Oshima et al. 1990).

Saxitoxin appeared in tissues of clams fed upon isolate GtLI22, although this toxin was not detected in the cell-free extracts of the dinoflagellates subjected to HPLC analysis. This de novo appearance of STX may originate from toxin biotransformation in tissues (e.g. conversion of $\mathrm{GTX}_{2+3}$ to STX through loss of an $\mathrm{SO}_{4}{ }^{2-}$ group), through artifactual conversion during sample preparation, or through progressive accumulation in clam tissues from initial levels below detection by HPLC. Any suggestion that the STX in the clam tissues is merely an artifact of the extraction procedure may be ruled out, given the care taken in preserving the integrity of the toxins by gentle acidification and proper storage. Considerably harsher treatment (e.g. heating in an inorganic acid) is normally required to effect significant conversion of other toxins to STX. Although the STX levels determined in the clam extracts were consistently low, they were well above detection limits $\left(0.02 \mathrm{umol}^{-1}\right)$. Furthermore, levels of STX were undetectable in extracts of the isolate GtLI22, although total toxin concentrations (in umol per volume injected) were always higher than in clam tissue extracts. Therefore, it is unlikely that STX accumulation to threshold detection levels can explain its appearance in the tissue samples.

The appearance of STX in bivalves fed Alexandrium catenella containing gonyautoxins or N-sulfocarbamoyl derivatives, but no detectable STX, has also been reported in butter clams Saxidomus giganteus (Sullivan 1982, Beitler \& Liston 1990). In these studies, however, STX appeared in clam tissues (primarily the siphon) after a considerable lag time, and a gradual increase in STX concentrations (in $\mu \mathrm{g} \mathrm{g}^{-1}$ ) was observed during decontamination. In contrast, in the present study, the concentration of STX remained fairly constant throughout the experiment (suggesting rapid conversion), although the percent contribution of STX to total toxicity increased over time as a result of changes in the relative levels of other toxins of lower potency (Fig. 8).

An increase in the proportion of STX in other tissues of clams fed upon Isolate GtCA29 was accompanied by a reduction in $\mathrm{C}_{1+2}$, neoSTX, and $\mathrm{GTX}_{1+4}$, although only the reduction in $\mathrm{C}$-toxins was statistically significant. An increase in the proportion of STX, and concomitant decrease in neoSTX and $\mathrm{GTX}_{3}$ during exposure to isolate GtCA29, was also observed in Mytilus edulis (Bricelj et al. 1990).

The $11 \beta$-hydroxysulfate epimers (e.g. GTX ${ }_{3}$, GTX $_{4}$ and $\mathrm{C}_{2}$ ) are often the favored chemical species synthesized in Alexandrium cells, while an increase in the proportions of the more stable $\alpha$-configuration (GTX $_{2}$, $\mathrm{GTX}_{1}, \mathrm{C}_{1}$ ) arises by epimerization once toxins are released through extraction or digestion (Wichmann et al. 1981, Hall et al. 1990). In this study, rapid epimerization of gonyautoxins occurred in all clam tissues during the toxin accumulation phase with both isolates. Epimerization can readily accur under most conditions of toxin storage (Hall et al. 1990), but since all tissue samples were treated equally prior to HPLC analysis, the temporal changes observed cannot be attributed to extraction or storage artifacts. Comparable rates of decline in the $\mathrm{GTX}_{3} / \mathrm{GTX}_{2}$ ratio in hard clam tissues were obtained with the 2 toxigenic isolates. A rapid decrease in the $\mathrm{GTX}_{3} / \mathrm{GTX}_{2}$ ratio was also reported in Mytilus edulis experimentally contaminated with isolate GtCA29 (Bricelj et al. 1990), and in field-collected mussels (Sullivan 1982). Therefore, during a toxic bloom, the epimer ratio could potentially serve as an indicator of the time since toxins were first accumulated by a bivalve species, as suggested by Hall et al. (1990). 


\section{CONCLUSIONS}

Several major conclusions can be drawn from these laboratory results with regard to the transfer and fate of paralytic shellfish toxins in Mercenaria mercenaria:

(1) Clams can attain toxin levels well above the harvest closure levels when exposed to either a monospecific bloom of a low-toxicity isolate such as GtLI22, or a mixed population of a highly toxic isolate such as GtCA29 and a non-toxic algal supplement, which acts as a stimulant of feeding activity.

(2) Mercenaria mercenaria detoxifies faster than other clam species such as Saxidomus giganteus and Spisula solidissima, and at rates comparable to those of the softshell clam Mya arenaria. We estimate that detoxification to acceptable levels for human consumption occurs within ca 24 to $44 \mathrm{~d}$ from initial disappearance of toxic cells

(3) The clams' ingestion rate of toxic cells, maximum body burden of toxin, and initial rates of detoxification vary markedly in response to differences in cell toxicity and/or toxin composition of the dinoflagellate cells consumed.

(4) The relative contribution of the visceral mass and other tissues to total toxicity, and the rate of epimerization of 11-hydroxysulfate toxins in clam tissues show similar patterns irrespective of the toxigenic isolate consumed.

(5) Significant alterations in the toxin profile of dinoflagellate cells take place in clam tissues during toxin uptake and detoxification, and the magnitude of these changes is greater when clams are offered an isolate rich in $\mathrm{N}$-sulfocarbamoyl toxins. Major changes involve: a significant decline in the proportion of $\mathrm{C}_{1+2}$ toxins, a reciprocal increase in the proportion of $\mathrm{GTX}_{2+3}$, and de novo appearance of STX in clams fed upon isolate GtLI22, and a significant increase in the relative content of STX in clams exposed to isolate GtCA29. The patterns observed are consistent with the metabolic conversion of less toxic sulfocarbamoyl to more potent carbamate toxin derivatives in clam tissues.

Acknowledgements. We thank D. M. Anderson (Woods Hole Oceanographic Institution, Woods Hole, MA) for providing the dinoflagellate isolates and for helpful discussions, J. Christie (SUNY Stony Brook) for algal culturing, R. Larocque and I. St. Pierre (Maurice Lamontagne Institute) for HPLC toxin analysis, and S. Buckner and the Town of Islip hatchery, NY, for supplying us with hard clams. J. Sullivan (formerly of USFDA, Seafood Products Division, Seattle, WA, USA) and Y Oshima (Tohoku University, Sendai, Japan) generously provided primary reference toxins for HPLC calibration. This work is the result of research sponsored by the NOAA Office of Sea Grant, U.S. Department of Commerce, under Grant \# NA86AADSG045 to the New York Sea Grant Institute, and by the Biological Oceanography Division, Maurice Lamontagne Institute, Dept. of Fisheries and Oceans (Canada).

\section{LITERATURE CITED}

Anderson, D. M. (1989). Toxic algal blooms and red tides: a global perspective. In: Okaichi, T., Anderson, D. M., Nemoto, T (eds.) Red tides: biology, environmental science, and toxicology. Elsevier, New York, p. 11-16

Anderson, D. M. (1990). Toxin variability in Alexandrium species. In: Graneli, E., Sundstrom, B., Edler, L., Anderson, D. M. (eds.) Toxic marine phytoplankton. Elsevier, New York, p. 41-51

Anderson, D. M., Kulis, D. M., Orphanos, J. A., Ceurvels, A. R. (1982). Distribution of the toxic dinoflagellate Gonyaulax tamarensis in the southern New England region. Estuar. coast. Shelf Sci. 14: 447-458

Bayne, B. L., Newell, R. C. (1983). Physiological energetics of marine molluscs. In: Saleuddin, A. S. M., Wilbur, K. M. (eds.) The Mollusca, Vol 4. Academic Press, New York, p. $407-515$

Bayne, B. L., Widdows, J., Worrall, C. (1977). Some temperature relationships in the physiology of two ecologically distinct bivalve populations. In: Vernberg, F. J., Calabrese, A., Thurberg, F. D., Vernberg, W. (eds.) Physiological responses of marine biota to pollutants. Academic Press, New York, p. 379-400

Beitler, M. K., Liston, J. (1990). Uptake and tissue distribution of PSP toxins in butter clams. In: Graneli, E., Sundstrom, B., Edler, L., Anderson, D. M. (eds.) Toxic marine phytoplankton. Elsevier, New York, p. 257-262

Blogoslawski, W. J., Stewart, M. E. (1978). Paralytic shellfish poison in Spisula solidissima: anatomical location and ozone detoxification. Mar Biol. 45: 261-264

Bond, R. M., Lachance, A. (1959). Toxicity records 1959. Dept Fish. Insp. Lab., St. Andrews, N.B

Boyer, G. L., Sullivan, J. J., Andersen, R. J., Taylor, F. J. R., Harrison, P. J., Cembella, A. D. (1986). Use of high-performance liquid chromatography to investigate the production of paralytic shellfish toxins by Protogonyaulax spp. in culture. Mar. Biol. 93: 361-369

Bricelj, V M., Lee, J. H., Cembella, A. D., Anderson, D. M. (1990). Uptake kinetics of paralytic shellfish toxins from the dinoflagellate Alexandrium fundyense in the mussel Mytilus edulis. Mar. Ecol. Prog. Ser. 63: 177-188

Cembella, A. D., Therriault, J. C. (1989). Population dynamics and toxin composition of Protogonyaulax tamarensis from the St. Lawrence estuary. In: Okaichi, T., Anderson, D. M., Nemoto, T. (eds.) Red tides: biology, environmental science, and toxicology. Elsevier, New York, p. 81-84

Cembella, A. D., Sullivan, J. J., Boyer, G. L., Taylor, F. J. R., Andersen, R. J. (1987). Variation in paralytic shellfish toxin composition within the Protogonyaulax tamarensis/ catenella species complex. Biochem. Syst. Ecol. 15: $171-186$

Cembella, A. D., Therriault, J.-C., Beland, P. (1988). Toxicity of cultured isolates and natural populations of Protogonyaulax tamarensis from the St. Lawrence estuary. J. Shellfish Res. 7. 611-621

Conover, R. J. (1966). Assimilation of organic matter by zooplankton. Limnol. Oceanogr 11: 338-345

Dupuy, J. L. (1968). Isolation, culture, and ecology of a source of paralytic shellfish toxin in Sequim Bay, Washington. Ph.D. dissertation, University of Washington

Guillard, R. R. L., Ryther, J. H. (1962). Studies of marine planktonic diatoms. I. Cyclotella nana Hustedt, and Detonula confervacea (Cleve) Gran. Can. J. Microbiol. 8: 229-239

Hall, S., Reichardt, P. B. (1984). Cryptic paralytic shellfish toxins. In: Ragelis, E. P. (ed.) Seafood toxins. ACS Sym- 
posium Series 262, American Chemical Society, Washington, D.C., p. 113-123

Hall, S., Strichartz, G., Moczydlowski, E., Ravindran, A. Reichardt, P. B. (1990). The saxitoxins. Sources, chemistry, and pharmacology. In: Hall, S. H., Strichartz, G. (eds.) Marine toxins. Origin, structure, and molecular pharmacology. ACS Symposium Series 418, American Chemical Society, Washington, D.C., p. 29-65

Hansen, P. J. (1989). The red tide dinoflagellate Alexandrium tamarense: effects on behaviour and growth of a tintinnid ciliate. Mar. Ecol. Prog. Ser. 53: 105-116

Hayhome, B. A., Anderson, D. M., Kulis, D. M., Whitten, D. J (1989). Variation among congeneric dinoflagellates from the northeastern United States and Canada. I. Enzyme electrophoresis. Mar. Biol. 101: 427-435

Hurst, J. W. Gilfillan, E. S. (1977). Paralytic shellfish poisoning in Maine. In: Wilt, E. S. (ed.) Tenth Natl. Shellfish Sanitation Workshop. U.S. Dept. Health, Education and Welfare, Food and Drug Administration, Washington, D.C., p. $152-161$

Ives, J. D. (1985). The relationship between Gonyaulax tamarensis cell toxin levels and copepod ingestion rates In: Anderson, D. M., White, A. W., Baden, D. G. (eds.) Toxic dinoflagellates. Elsevier, New York, p. 413-418

Ives, J. D. (1987). Possible mechanisms underlying copepods grazing responses to levels of toxicity in red tide dinoflagellates. J. exp. mar. Biol. Ecol. 112: 131-145

Keller, M. D., Selvin, R. C., Claus, W., Guillard, R. L. (1987) Media for the culture of oceanic ultraphytoplankton. J Phycol. 23: 633-638

Kvitek, R. G., Beitler, M. K. (1991). Relative insensitivity of butter clam neurons to saxitoxin: a preadaptation for sequestering paralytic shellfish poisoning toxins as a chemical defense. Mar. Ecol. Prog. Ser. 69: 47-54

Lassus, P., Fremy, J.-M., Ledoux, M.,Bardouil, M., Bohec, M (1989). Patterns of experimental contamination by Protogonyaulax tamarensis in some French commercial shell. fish. Toxicon 27: 1313-1321

Madenwald, N. D. (1985). Effect of water temperature on the loss of paralytic shellfish poison from the butter clam, Saxidomus giganteus. In: Anderson, D. M., White, A. W. Baden, D. G. (eds.) Toxic dinoflagellates. Elsevier, New York, p. $479-484$

Malouf, R. E., Bricelj, V M. (1989). Comparative biology of clams: environmental tolerances, feeding, and growth. In Manzi, J. J., Castagna, M. (eds.) Clam mariculture in North America. Elsevier, New York, p. 23-73

Maranda, L., Anderson, D. M., Shimizu, Y (1985). Comparison of toxicity between populations of Gonyaulax tamarensis of eastern North American waters. Estuar. coast. Shelf Sci. 21: 401-410

Martin, J L, White, A. W. Sullivan, J. J. (1990). Anatomical distribution of paralytic shellfish toxins in soft-shell clams. In: Graneli, E., Sundstrom, B., Edler, L., Anderson, D. M (eds.) Toxic marine phytoplankton. Elsevier. New York, p. $379-384$

This article was presented by J. M. Shick, Orono, Maine, US.A
Oshima, Y., Sugino, K, Itakura, H., Hirota, M., Yasumoto, T (1990). Comparative studies on paralytic shellfish toxin profile of dinoflagellates and bivalves. In: Graneli, E., Sundstrom, B., Edler, L., Anderson, D. M. (eds.) Toxic marine phytoplankton. Elsevier, New York, p. 391-396

Quayle, D. B. (1969). Paralytic shellfish poisoning in British Columbia, Bull. Fish. Res. Bd Can. 168: 68 pp

Schrey, S. E., Carpenter, E. J., Anderson, D. M. (1984). The abundance and distribution of the toxic dinoflagellate Gonyaulax tamarensis, in Long Island estuaries. Estuaries 7: $472-477$

Shimizu, Y (1978). Dinoflagellate toxins. In: Scheuer, P. J. (ed.) Marine natural products. Academic Press, New York, p. $1-42$

Shimizu, Y., Yoshioka, M. (1981). Transformation of paralytic shellfish as demonstrated in scallop homogenates. Science 212: $547-549$

Shumway, S. E. (1990a). Auditing the impact of toxic algal blooms on oysters. Environm. Auditor 2: 41-56

Shumway, S. E. (1990b). A review of the effects of algal blooms on shellfish and aquaculture. J. World Aquacult. Soc. 21: $65-104$

Shumway, S. E., Cucci, T. R. (1987). The effects of the toxic dinoflagellate Protogonyaulax tamarensis on the feeding and behaviour of bivalve molluscs. Aquat. Toxicol. 10: $9-27$

Shumway, S. E., Sherman-Caswell, S., Hurst, J. W. (1988). Paralytic shellfish poisoning: monitoring a monster. J. Shellfish Res. 7: 643-652

Sokal, R. R., Rohlf, F. J. (1981). Biometry, 2nd edn. W. H. Freeman \& Co. San Francisco

Sullivan, J. J. (1982). Paralytic shellfish poisoning: analytical and biochemical investigations. Ph.D. dissertation, University of Washington, Seattle

Sullivan, J. J. (1990). High-performance liquid chromatographic method applied to paralytic shellfish poisoning research. In: Hall, S. H., Strichartz, G. (eds.) Marine toxins. Origin, structure, and molecular pharmacology. ACS Symposium Series 418, American Chemical Society, Washington, D.C., p. 66-77

Sullivan, J. J., Iwaoka, W. T., Liston, J. (1983). Enzymatic transformation of PSP toxins in the littleneck clam (Protothaca staminea). Biochem. Biophys. Res. Commun. 114 : $465-472$

Twarog, B. M., Hidaka, T., Yamaguchi, H. (1972). Resistance to tetrodotoxin and saxitoxin in nerves of bivalve molluscs. Toxicon 10: 273-278

Twarog, B. M., Yamaguchi, H. (1974). Resistance of paralytic shellfish toxins in bivalve molluscs. In: LoCicero, V. R. (ed.) Proc. First Int. Conf. on toxic dinoflagellate blooms. Mass. Science and Technology Fund, Wakefield, Massachusetts, p. 382-393

Wichmann, C. F., Boyer, G. L., Divan, C. L., Schantz, E. J., Schnoes, H. K. (1981). Neurotoxins of Gonyaulax excavata and Bay of Fundy scallops. Tetrahedron Lett. 22: $1941-1944$

Manuscript first received: January 2, 1991

Revised version accepted: April 23,1991 